
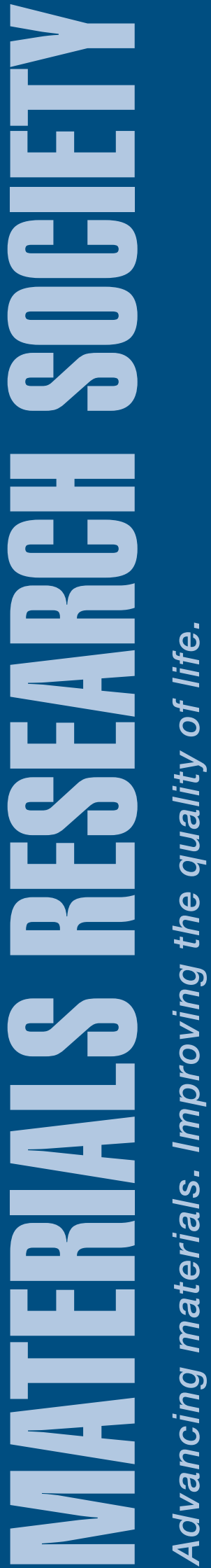

We face an economic crisis of unknown proportions. Many individuals and businesses will unfairly suffer from unpredictable events, and many of these will be difficult to counter. We can hope to balance the economic fallout with opportunities for growth.

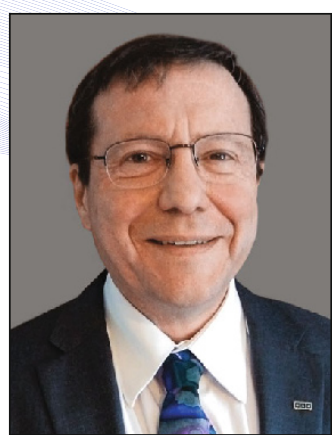

\title{
Navigating unprecedented
} times

Matt Copel

2020 MRS President

$\mathrm{I}^{\mathrm{N}}$ light of the extraordinary challenges brought on by the novel coronavirus (COVID-19) pandemic, many of us are wondering how to respond as scientists and responsible citizens. Of course, we all have primary responsibilities to keep our families, neighbors, and colleagues safe. Sparing a vulnerable friend a trip to the grocery store or donating some cleaning supplies to your food bank are examples of actions I encourage us all to take. For those who are personally touched by the pandemic, we hope that the support of our community is a source of strength. Many of us may also be wondering what more we can do in our professional capacities. Are there any actions we can take to alleviate our frustrations as we follow stay-at-home orders?

Many MRS members study scientific areas with a direct or indirect impact on fighting infectious diseases (see table on next page). Researchers who work on these, or a host of similar problems, are well-positioned to help society mount effective defenses against global infections - we applaud their efforts. For those of us involved in research with no immediate influence on public health, it may be less clear how we can help. However, there still are actions we can take that will have long-term benefits for society.

We face an economic crisis of unknown proportions. Many individuals and businesses will unfairly suffer from unpredictable events, and many of these will be difficult to counter. We can hope to balance the economic fallout with opportunities for growth. Many MRS members are entrepreneurs who we will count on to deliver innovations that can stimulate the economy and help us recover from the damage to our financial well-being. We can also join MRS members in advocating for stimulus research funding to help develop needed solutions, such as support for universities and graduate students as well as for small businesses and other governmental relief to aid those most affected by the current societal and economic upheaval.

A large number of MRS members are engaged in education. Indeed, our educators bear a heavy burden with the forced transition to the virtual classroom and the disruption of their research programs. We are also witnessing the rise of pseudoscience and the neglect of proven methods for defending ourselves against pandemics, emphasizing the importance of fundamental understanding of science. Educators are the front line in helping the next generation of students, and the public at large, to recognize the need for sound science to protect society and to advance the quality of life. All of us, in every sector of our community, can engage with legislators and agencies to ensure that experts are part of the process to define policies aimed at taking effective measures to stem the current pandemic and to prevent future outbreaks. 
Areas of materials relevance to COVID-19

\begin{tabular}{|c|l|}
\hline Topic & \multicolumn{1}{|c|}{ Description } \\
\hline Virus structure & $\begin{array}{l}\text { Characterization, imaging, and analysis of the structure and its } \\
\text { modification; protein assembly }\end{array}$ \\
\hline Detection & $\begin{array}{l}\text { Sensing, testing methods/kits for the virus and antibodies; bioassays, } \\
\text { ELISA (enzyme-linked immunosorbent assay), in vivo electronic } \\
\text { devices (including transient electronics), polymerase chain reactions, } \\
\text { modeling of the epidemic }\end{array}$ \\
\hline $\begin{array}{c}\text { Therapeutics/ } \\
\text { treatment }\end{array}$ & $\begin{array}{l}\text { Nanoparticles or synthetic biology to detect, interfere with, or target the } \\
\text { virus; virus capsids as tools for immunology and drug delivery; materials } \\
\text { for vaccines; designs for new ventilators and systems to deliver oxygen } \\
\text { (zeolites to concentrate oxygen, metal-organic frameworks) }\end{array}$ \\
\hline $\begin{array}{c}\text { Testing/ } \\
\text { modeling }\end{array}$ & $\begin{array}{l}\text { Lab-on-a-chip, simulations, combinatorial or artificial intelligence } \\
\text { methods to speed research }\end{array}$ \\
\hline Protective gear & $\begin{array}{l}\text { Design of mask materials/membranes for filtration, microfluidics, } \\
\text { rapid manufacturing, 3D printing, antiviral coatings, surface cleaning } \\
\text { for masks, shields, clothing, etc. }\end{array}$ \\
\hline $\begin{array}{c}\text { Surface } \\
\text { sanitation }\end{array}$ & $\begin{array}{l}\text { Surface pathogens, detection and lifetimes on surfaces, antiviral } \\
\text { surface design/coatings, chemical reactions }\end{array}$ \\
\hline
\end{tabular}

Information courtesy of Betsy Fleischer and Gopal Rao.

Finally, let's discuss the decision to cancel the 2020 MRS Spring Meeting. Of course, this was a necessary response to public health measures and our responsibility to protect our members and the community. MRS appreciates the tremendous effort on the part of volunteers, staff, and contributors to create the Meeting program. MRS also recognizes that our presenters were especially affected by the cancellation of the 2020 MRS Spring Meeting. It is our intent to reschedule as much of the program as feasible. We are also offering free MRS membership through 2020 to all presenters who do not currently have a membership through that time frame. We will work with them to facilitate timely publication of their research, as well as participation at future MRS events to engage and network with the community. This is not an ideal solution, but it reflects a commitment by MRS to serve our members.

I want to publicly thank staff and volunteers for the extraordinary dedication they have shown to MRS during this demanding period. I have been repeatedly impressed with their professionalism and capability in dealing with these setbacks, and I can't thank them enough.

My hope is that this letter will encourage creative thinking about actions we can take.

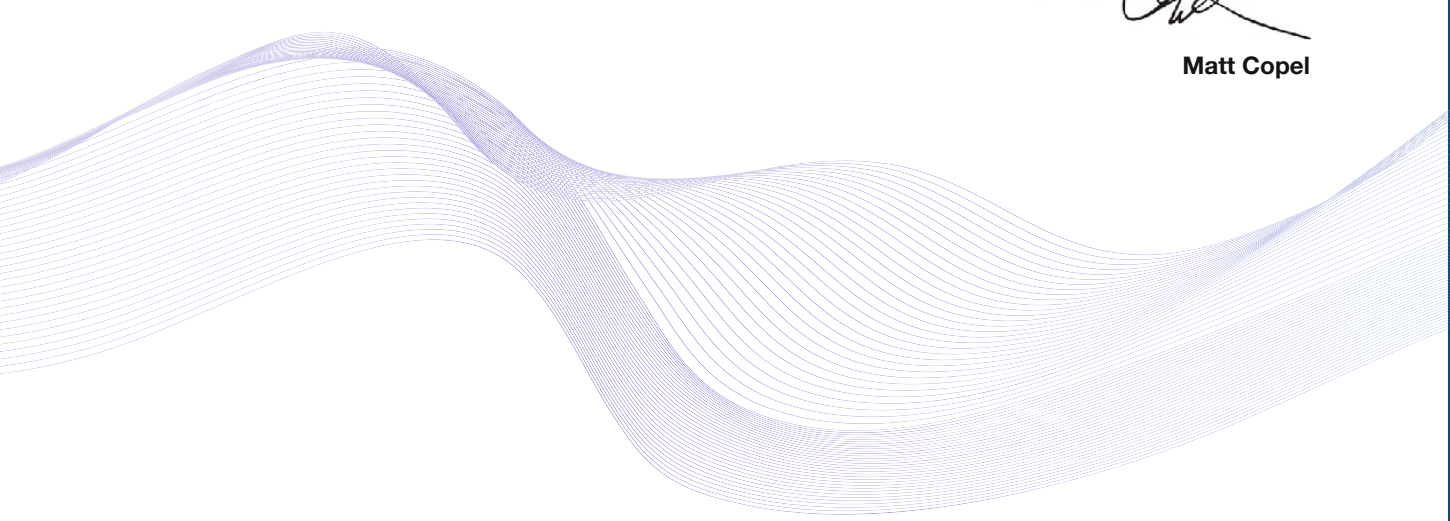

